\title{
Short communication: Potential use of passion fruit (Passiflora cincinnata) as a biopreservative in the production of coalho cheese, a traditional Brazilian cheese
}

\author{
Camila F. Costa, ${ }^{1}$ Andressa Fusieger, ${ }^{2}$ Milimani Andretta, ${ }^{3}$ Anderson C. Camargo, ${ }^{3}$ Antonio F. Carvalho, ${ }^{2}$ \\ Daniel R. Menezes, ${ }^{1 *}$ and Luís A. Nero ${ }^{3 *}$ \\ ${ }^{1}$ Departamento Medicina Veterinária, UNIVASF, Petrolina 56304917 PE Brazil \\ ${ }^{2}$ Departamento Tecnologia de Alimentos, UFV, Viçosa 36570900 MG Brazil \\ ${ }^{3}$ Labortório de Inspeção de Produtos de Origem Animal, Departamento de Veterinária, Universidade Federal de Viçosa, \\ Viçosa 36570900 MG Brazil
}

\section{ABSTRACT}

Passion fruit (Passiflora cincinnata Mast.) is a native fruit from the Caatinga, a typical ecoregion in northeastern Brazil, and it has potential for use by the food and pharmaceutical industries. In this study, we characterized the antimicrobial activity of $P$. cincinnata and its application in the production of coalho cheese, a traditional Brazilian product. Aqueous extract of $P$. cincinnata exhibited high inhibitory activity against Listeria spp. ( $\mathrm{n}=4$, reference strains), Staphylococcus aureus ( $\mathrm{n}=3$, reference strains), and multidrug-resistant Staph. aureus $(\mathrm{n}=8)$, and low inhibitory activity against lactic acid bacteria ( $\mathrm{LAB}, \mathrm{n}=3$, reference strains). Based on these results, we produced coalho cheese using goat milk with and without (control) passion fruit. Cheeses were stored at $10^{\circ} \mathrm{C}$ for $14 \mathrm{~d}$ and populations of mesophilic aerobes, Staph. aureus, and presumptive $\mathrm{LAB}$ were monitored at $\mathrm{d} 1,7$ and 14 . The passion fruit cheese had lower counts of mesophilic aerobes, Staph. aureus (after 7 and $14 \mathrm{~d}$ ), and presumptive LAB (after $14 \mathrm{~d}$ ) than the control cheese. Adding ground passion fruit contributed to a reduction of Staph. aureus counts in goat cheese, although these differences were not significant. These results indicated the inhibitory potential of passion fruit and its potential use for controlling microbial populations in a cheese model; further studies are needed to characterize the active molecules that are responsible for such activity. Key words: Passiflora cincinnata, passion fruit, antimicrobial activity, goat coalho cheese

Received October 25, 2019.

Accepted December 19, 2019.

*Corresponding authors: daniel.menezes@univasf.edu.br and nero@ ufv.br

\section{Short Communication}

Passiflora cincinnata Mast., also known as "passion fruit from Caatinga," is a native plant species from semi-arid regions mainly in northeastern Brazil, in the states of Bahia, Pernambuco, Alagoas, and Sergipe (Oliveira and Ruggiero, 2005). This plant species is well adapted to local cultivation conditions in northeastern Brazil and highly resistant to pests and diseases (Araujo, 2007). Passiflora cincinnata has been found to have aromatic metabolites, substances with antimicrobial activity and antioxidant potential, and is able to reduce nociceptive and inflammatory events in mice (de Lavor et al., 2018; Leal et al., 2018; Siebra et al., 2018). These beneficial properties are important features when evaluating $P$. cincinnata as a potential producer of novel bioactive compounds that could be exploited by the food and pharmaceutical industries (Joana Gil-Chávez et al., 2013).

Natural products have emerged as an alternative option for food preservation. Some plant extracts and essential oils have demonstrated inhibitory activity against pathogens and spoilage bacteria, even in complex food matrixes such as cheeses (Tayel et al., 2015; Khorshidian et al., 2018). Siebra et al. (2018) showed that hydroalcoholic extracts of $P$. cincinnata are potential antimicrobial agents against Staphylococcus aureus and Escherichia coli when associated with conventional drugs. However, the effects of $P$. cincinnata on the growth of desirable and other contaminant microorganisms has not yet been evaluated in a food matrix.

Coalho cheese is a traditional Brazilian cheese produced mainly by small-scale goat farmers, and thus having social and economic relevance for the region. Despite being considered a local product, coalho cheese is consumed in different Brazilian states, and its identity and quality standards have been established by the Brazilian Ministry of Agriculture. It is characterized 
as a medium- to high-moisture cheese that must be consumed within $10 \mathrm{~d}$ after production (Brasil, 1996, 2001). This cheese is often associated with poor hygienic conditions that can result in rapid spoilage during storage and reduced shelf life (Azevêdo et al., 2014; Pereira et al., 2018). Previous studies have demonstrated that compounds such as plant extracts or oils can be used as preservatives to enhance cheese quality (Shan et al., 2011; Bukvicki et al., 2018; Khorshidian et al., 2018; Pereira et al., 2018). In this regard, passion fruit could be exploited as an ingredient in coalho cheese production. In this study, we aimed to assess the inhibitory activity of passion fruit against different bacteria and evaluate its potential use as a bioactive ingredient for production of coalho cheese.

Passion fruits were harvested in the municipality of

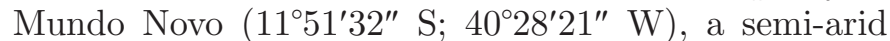
region of Bahia, Brazil. The fruits were washed, cut, and placed in a forced circulation oven at $45^{\circ} \mathrm{C}$ for 72 $\mathrm{h}$, ground aseptically, and stored at room temperature. Preparation of the aqueous extract was carried out as recommended by Mohanta et al. (2017), with modifications. Briefly, the ground passion fruit was macerated with distilled water (1:1) for $20 \mathrm{~min}$ and centrifuged for $15 \mathrm{~min}(3,260 \times \mathrm{g})$ at $10^{\circ} \mathrm{C}$; then, the supernatant was aseptically filtered $(0.22 \mu \mathrm{m}$, syringe filter K18230, KASVI, São José dos Pinhais, PR, Brazil). The semi-purified extract was used for microbiological assays immediately after preparation.

The antimicrobial activity of semi-purified extract was determined against bacteria usually associated with dairy products: lactic acid bacteria (LAB; Lactobacillus sakei ATCC 15521, Lactococcus lactis ssp. cremoris ATCC 19257, Lactococcus lactis ssp. lactis ATCC 13675), Listeria spp. (Listeria monocytogenes Scott A, ATCC 15313, and ATCC 19112, and Listeria innocua ATCC 33090), and Staph. aureus [ATCC 6538, ATCC 14458, ATCC 12598, and 8 multi-drug resistant isolates, obtained from goat milk (Lima et al., 2018) and from goat milk cheese (isolates obtained in our laboratory, unpublished)]. The isolates were stored at $-80^{\circ} \mathrm{C}$ in de Man, Rogosa, and Sharpe broth (MRS, Becton, Dickinson and Co., Franklin Lakes, NJ) or brain heart infusion (BHI, Oxoid Ltd., Basingstoke, UK) in 20\% (vol/vol) glycerol; before use, isolates were transferred to $\mathrm{BHI}$ or MRS, incubated at $37^{\circ} \mathrm{C}$ overnight, and checked for purity in trypticase soy agar (TSA, Oxoid) or MRS agar after incubation at $37^{\circ} \mathrm{C}$. Then, a single colony from each strain was transferred to BHI (Oxoid), incubated at $37^{\circ} \mathrm{C}$ overnight, and diluted with BHI to a turbidity similar to tube 1 of the MacFarland scale, equivalent to approximately $3 \times 10^{8}$ $\mathrm{cfu} / \mathrm{mL}$; these cultures were used for the in vitro assessment of inhibitory activity of $P$. cincinnata fruits.
Inhibitory activity of semi-purified extract of $P$. cincinnata was assessed by using 96-well dilution plates. To each well was added $150 \mu \mathrm{L}$ of semi-purified extract and $150 \mu \mathrm{L}$ of target culture (approximately $10^{4} \mathrm{cfu} /$ $\mathrm{mL}$ ) and plates were incubated at $37^{\circ} \mathrm{C}$ for $24 \mathrm{~h}$ in a Multiskan GO Microplate Spectrophotometer (Thermo Fisher Scientific, Madison, WI). The optical densities of the cultures were measured at $600 \mathrm{~nm}$ every $30 \mathrm{~min}$ (Vijayakumar and Muriana, 2015). Wells without the semi-purified extract were used as controls for growth of microbial reference target, with $150 \mu \mathrm{L}$ of sterile water added to make the final volume. Two independent experiments were carried out in triplicate.

Based on the obtained results, ground $P$. cincinnata fruit was used as an ingredient for the production of coalho cheese, as described by Rincón et al. (2017), with modifications. Two treatments were considered: control coalho cheese (CCC) and passion fruit coalho cheese (PFCC; Figure 1). The CCC was produced with $2 \mathrm{~L}$ of goat milk mixed with $0.025 \mathrm{~mL}$ of coagulant (bovine chymosin, Maxiren XDS, DSM Food Specialties, Delft, the Netherlands); coagulation was conducted at $35^{\circ} \mathrm{C}$ for 20 min, after which the curd was cut and mixed for 40 min to obtain grains $5 \mathrm{~mm}$ in diameter and then mixed with $15 \mathrm{~g}$ of salt. The whey was drained by pressure and 200- to 250 -g cheeses were molded (24 h), packed in plastic packages, and kept at $10^{\circ} \mathrm{C}$ in a ripening chamber with 85 to $86 \%$ relative humidity. The PFCC was produced following the same procedure, except that 60 $\mathrm{g}$ of ground passion fruit was added directly to the $2 \mathrm{~L}$ of goat milk in the first production step. Cheeses were produced in 3 independent repetitions.

Cheeses were subjected to microbial analysis during storage. After 1, 7, and $14 \mathrm{~d}$, cheese units were collected, and portions of $25 \mathrm{~g}$ were aseptically obtained, transferred to sterile bags with $225 \mathrm{~mL}$ of citrate solution $(0.85 \%$, wt $/ \mathrm{vol})$, homogenized, and 10 -fold diluted in $\mathrm{NaCl} 0.85 \%$ (wt/vol). Selected dilutions were plated onto Petrifilm STX, Petrifilm AC (3M Microbiology, St. Paul, MN), and acidified MRS agar (pH 5.7; Njongmeta et al., 2005), for enumeration of Staph. aureus, mesophilic aerobes, and presumptive LAB, respectively. Plates were incubated at $35^{\circ} \mathrm{C}$ for $24 \mathrm{~h}$ (Petrifilm AC), $48 \mathrm{~h}$ (Petrifilm STX), and $72 \mathrm{~h}$ (LAB), after which the typical colonies were enumerated and the results expressed as colony-forming units per gram. Counts were converted to $\log _{10}$ and results were compared considering the treatments and storage days by ANOVA and Tukey honestly significant difference (HSD) test $(P<0.05)$, using XLSTAT software (Addinsoft, New York, NY).

Passion fruit is widely used in Brazil, especially in the northeastern region, for preparing beverages and in popular medicine, because of its potential applica- 
tion as a sedative, antioxidant, and anxiolytic (Dhawan et al., 2004; Leal et al., 2018). It is well known that extracts of certain plants can increase the quality and sensory attributes of foods because of their antimicrobial and antioxidant activity and the presence of pleasant aromatic compounds and coloring characteristics; however, these extracts must be characterized before proper application (Tayel et al., 2013). All microbial targets included in this study were inhibited in vitro by the semi-purified extract of $P$. cincinnata but growth of LAB was less inhibited than growth of Listeria spp.

\section{Raw goat milk (2 L)}

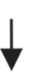

\section{Adding coagulant to the raw milk $\left(35^{\circ} \mathrm{C}\right)(\mathrm{CCC})$}

or

\section{Adding coagulant to the raw milk $\left(35^{\circ} \mathrm{C}\right)$ plus ground passion fruit (PFCC)}

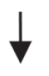

Coagulation step $\left(35^{\circ} \mathrm{C}\right)$

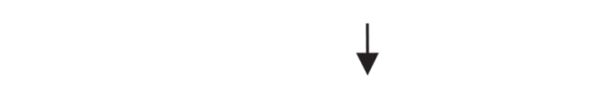

Curd cutting and mixing $\left(47^{\circ} \mathrm{C} / 40 \mathrm{~min}\right)$

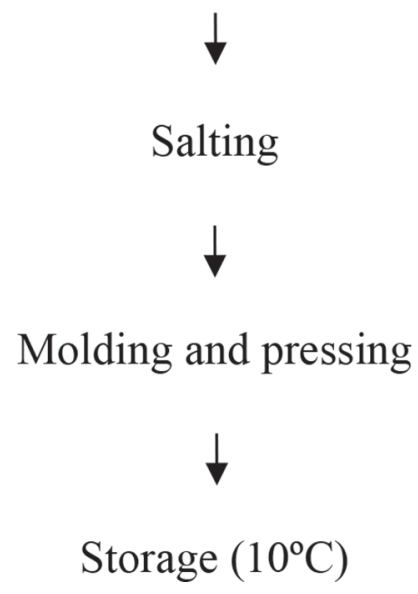

Figure 1. Goat milk coalho cheese production, demonstrating the differences for control coalho cheese (CCC) and passion fruit coalho cheese (PFCC). or Staph. aureus (Figure 2). The high inhibitory effect against multidrug-resistant Staph. aureus is particularly relevant in milk and cheeses made with raw goat milk, niches that are the focus of the application of $P$. cincinnata as a biopreservative.

The antimicrobial activity observed against Staph. aureus is relevant because this species is the most frequent cause of mastitis in dairy-producing animals and often associated with foodborne outbreaks (Smith, 2015; Kong et al., 2016; Lima et al., 2018). Also, Staph. aureus and Listeria monocytogenes are often linked to contaminated dairy products (Smith, 2015; Kong et al., 2016; Maury et al., 2019). Siebra et al. (2018) showed that conjugation of hydroalcoholic extract of $P$. cincinnata with antibiotics resulted in synergistic activity against multidrug-resistant Staph. aureus and E. coli. Further studies are warranted to assess the association of $P$. cincinnata bioactive compounds with conventional drugs, such as aminoglycosides and $\beta$-lactams, which alone are not very effective against multidrug-resistant strains (de Carvalho et al., 2019).

Terpenoids and phenolic compounds are the usual substances obtained from plants with antimicrobial activity, and these substances are reportedly produced by P. cincinnata (Costa et al., 2016; Leal et al., 2018). Phenolic substances, in particular, have potential application in food systems as antioxidants: low concentrations of phenolic acids act negatively on microbial enzymatic activity and high concentrations cause protein denaturation (Hassanien et al., 2014). Flavonoids have a strong effect on biological systems, demonstrating antimicrobial, antiviral, antioxidant, antihepatotoxic, antiulcerogenic, antihypertensive, and anti-inflammatory effects (Dhawan et al., 2004). According to Tajkarimi et al. (2010), other mechanisms of these compounds relate to their ability to alter the permeability of the microbial cell or the function of the cell membrane, or from effects on nutrient absorption, electron transport, and enzymatic activity to synthesize nucleic acids.

The inhibitory effect of $P$. cincinnata on growth of selected microbial groups in the goat milk coalho cheese model are presented in Figure 3. Growth of Staph. aureus was inhibited by the presence of the ground dried passion fruit, although no significant differences were observed between CCC and PFCC $(P>0.05)$. We did observe significant differences in growth of LAB and mesophilic aerobes in PFCC (Figure 3). These differences were clearly observed after $7 \mathrm{~d}$ of storage, which would be expected due to the potential release of bioactive compounds by the dried passion fruit in the PFCC. However, the antimicrobial effects of ground fruit in cheese were much lower compared with effects reported in in vitro studies (Figure 2). According to 

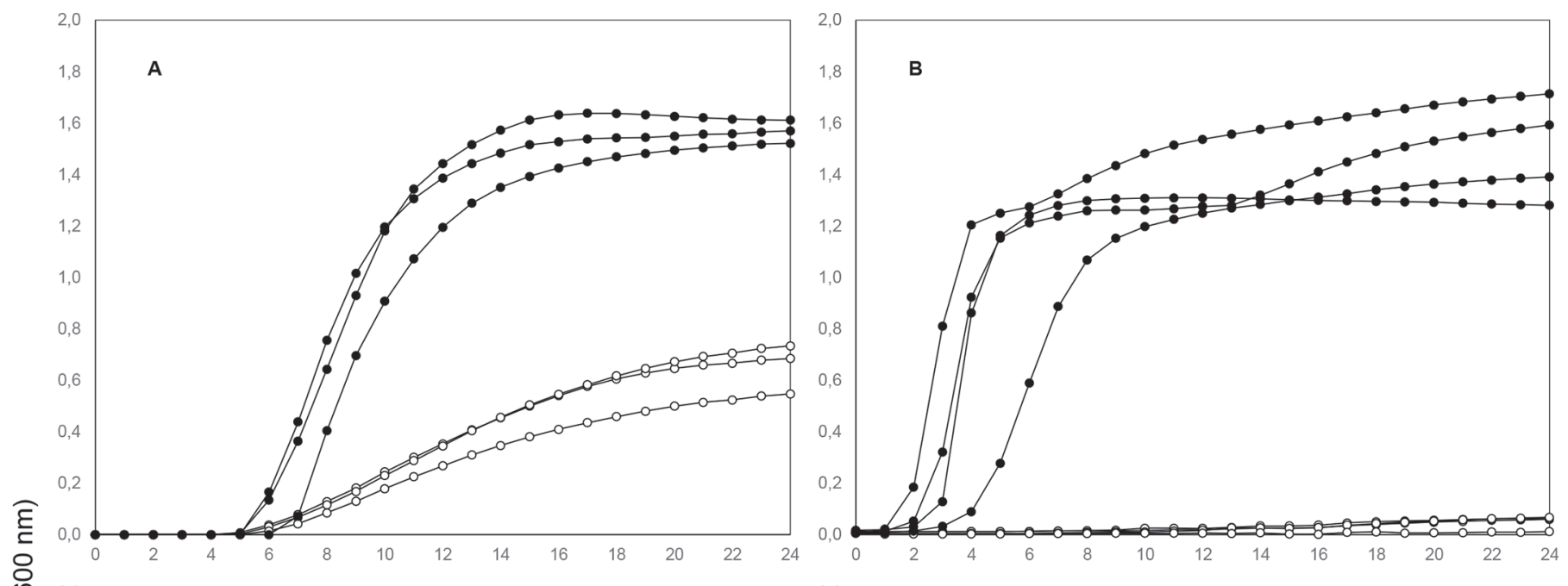

○
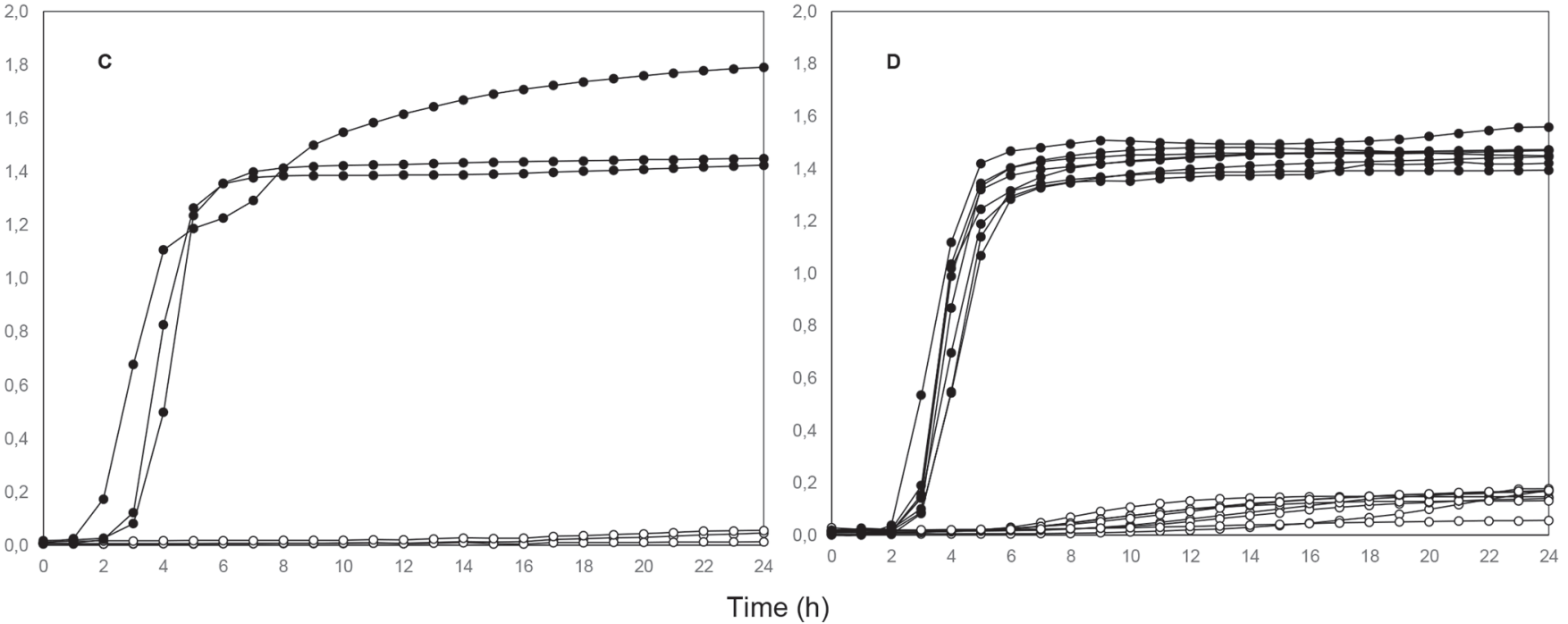

Figure 2. Growth curves (optical density at $600 \mathrm{~nm}$ ) of selected strains of lactic acid bacteria (A), Listeria spp. (B), Staphylococcus aureus (C), and multidrug-resistant Staph. aureus (D) in brain heart infusion (control, $\bullet$ ) and in the presence of a semipurified extract of passion fruit (O), incubated at $37^{\circ} \mathrm{C}$ for up to $24 \mathrm{~h}$.

Gutierrez et al. (2008), the lipid and protein contents of dairy products are intrinsic factors that can impair the effectiveness of natural antimicrobial substances. Fat and protein can cover the bacterial surface, forming a protective capsule that prevents contact with the bioactive compound. This effect was confirmed by Cava et al. (2007), who observed reduced antimicrobial activity of cinnamon and cloves in high-fat milk samples compared with skim milk samples. Because cheese has high levels of fat and protein, the concentrations of natural compounds that must be added to achieve microbiological inhibition must be higher than those tested in vitro (Shan et al., 2011; Amatiste et al., 2014). These findings are in agreement with our observations, perhaps because goat coalho cheese has a high lipid content (Rincón et al., 2017).
In the present study, we demonstrated potential use of $P$. cincinnata in controlling the growth of pathogenic bacteria often associated with dairy products, including multidrug-resistant bacteria. We propose its use as a bioactive ingredient in the production of coalho cheese. Further studies will characterize the bioactive compounds in $P$. cincinnata and their potential use for application in food systems.

\section{ACKNOWLEDGMENTS}

The study was supported by Conselho Nacional de Desenvolvimento Científico e Tecnológico (CNPq, Brasília, DF, Brazil), Fundação de Amparo à Pesquisa do Estado de Minas Gerais (FAPEMIG, Belo Horizonte, MG, Brazil) and Coordenação de Aperfeiçoamento de 

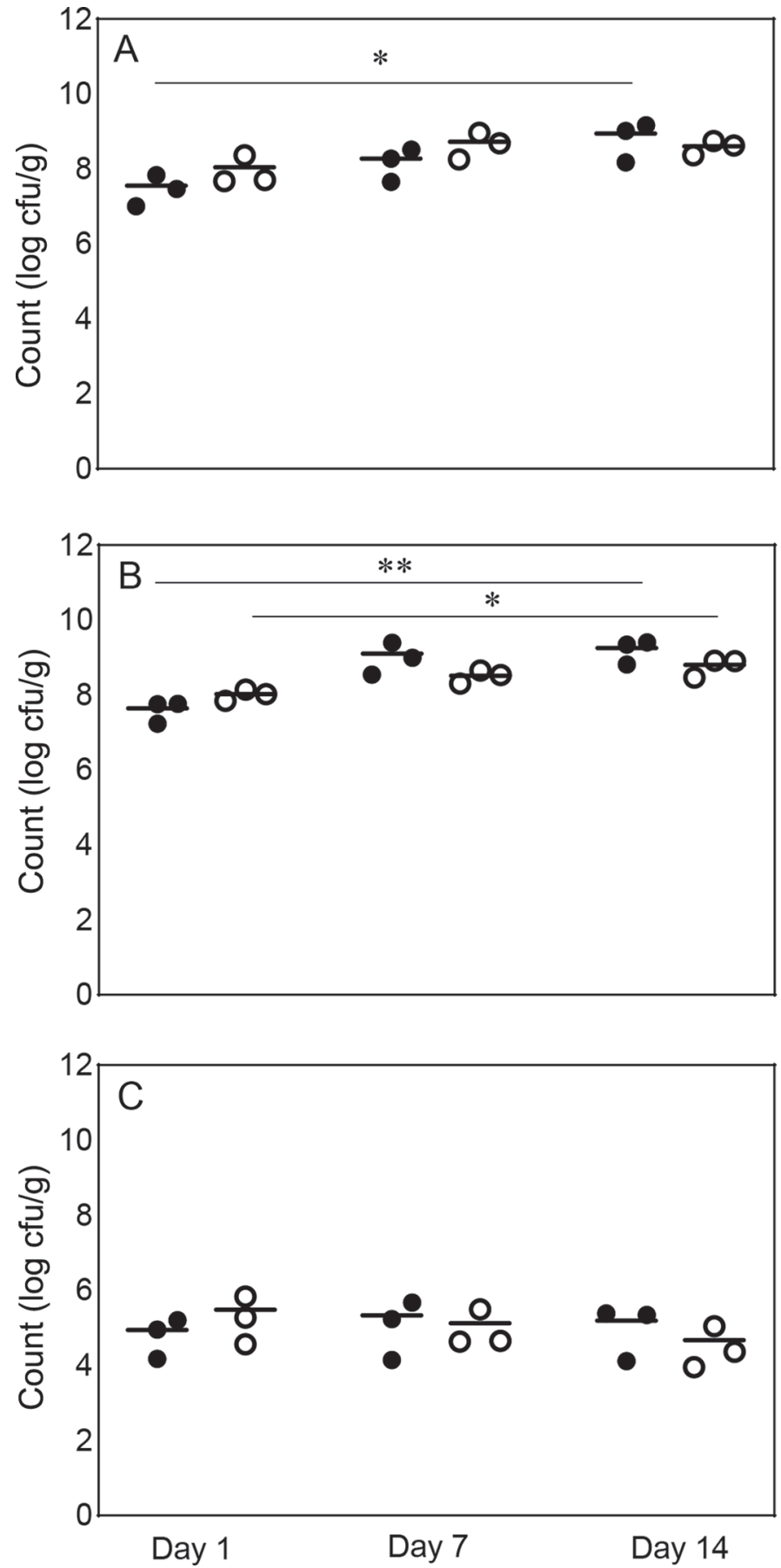

Figure 3. Growth of presumptive lactic acid bacteria (A), mesophilic aerobes (B), and Staphylococcus aureus (C) in control (-) and passion fruit $(\mathrm{O})$ coalho cheese models stored at $10^{\circ} \mathrm{C}$ for up to $14 \mathrm{~d}$. ${ }^{*} P<0.05 ;{ }^{* *} P<0.005$, Tukey honestly significant difference test.

Pessoal de Nível Superior (CAPES, Brasília, DF, Brazil, Financial code 001). The authors have not stated any conflicts of interest.

\section{REFERENCES}

Amatiste, S., D. Sagrafoli, G. Giacinti, G. Rosa, V. Carfora, N. Marri, A. Tammaro, E. Bovi, and R. Rosati. 2014. Antimicrobial activity of essential oils against Staphylococcus aureus in fresh sheep cheese. Ital. J. Food Saf. 3:1696. https://doi.org/10.4081/ijfs.2014.1696.

Araujo, F. P. 2007. Caracterização da variabilidade morfoagronômica de maracujazeiro (Passiflora cincinnata Mast.) no semi-árido brasileiro. Page 94 in Doutorado em Horticultura. Vol. Doctorate. Universidade Estadual Paulista, Botucatu, SP, Brazil.

Azevêdo, M. C., G. B. Santos, F. Zocche, M. C. Horta, F. S. Dias, and M. M. Costa. 2014. Microbiological evaluation of raw milk and coalho cheese commercialised in the semi-arid region of Pernambuco, Brazil. Afr. J. Microbiol. Res. 8:222-229. https://doi.org/10.5897/ AJMR2013.6476.

Brasil. 1996. Ministério da Agricultura, Pecuária e Abastecimento. Portaria no. 146, de 07 de março de 1996. Aprova os Regulamentos Técnicos de Identidade e Qualidade de Produtos Lácteos. Diário Oficial da União, 11 de março de 1996, Brasília, Brazil.

Brasil. 2001. Ministério da Agricultura, Pecuária e Abastecimento. Instrução Normativa no. 30, de 26 de junho de 2001. Aprova os Regulamentos Técnicos de Identidade e Qualidade de Manteiga da Terra ou Manteiga de Garrafa; Queijo de Coalho e Queijo de Manteiga, conforme consta dos Anexos desta Instrução Normativa. Diário Oficial da União, 16 de julho de 2001, Brasília, Brazil.

Bukvicki, D., A. Giweli, D. Stojkovic, L. Vujisic, V. Tesevic, M. Nikolic, M. Sokovic, and P. D. Marin. 2018. Short communication: Cheese supplemented with Thymus algeriensis oil, a potential natural food preservative. J. Dairy Sci. 101:3859-3865. https://doi .org/10.3168/jds.2017-13714.

Cava, R., E. Nowak, A. Taboada, and F. Marin-Iniesta. 2007. Antimicrobial activity of clove and cinnamon essential oils against Listeria monocytogenes in pasteurized milk. J. Food Prot. 70:27572763. https://doi.org/10.4315/0362-028X-70.12.2757.

Costa, G. M., A. C. Gazola, S. M. Zucolotto, L. Castellanos, F. A. Ramos, F. H. Reginatto, and E. P. Schenkel. 2016. Chemical profiles of traditional preparations of four South American Passiflora species by chromatographic and capillary electrophoretic techniques. Rev. Bras. Farmacogn. 26:451-458. https://doi.org/10.1016/j.bjp .2016.02.005.

de Carvalho, S. P., J. B. Almeida, L. M. Freitas, A. M. S. Guimarães, N. C. Nascimento, A. P. Santos, G. B. Campos, J. B. Messick, J. Timenetsky, and L. M. Marques. 2019. Genomic profile of Brazilian methicillin-resistant Staphylococcus aureus resembles clones dispersed worldwide. J. Med. Microbiol. 68:693-702. https://doi .org/10.1099/jmm.0.000956

Dhawan, K., S. Dhawan, and A. Sharma. 2004. Passiflora: A review update. J. Ethnopharmacol. 94:1-23. https://doi.org/10.1016/j .jep.2004.02.023.

Gutierrez, J., C. Barry-Ryan, and P. Bourke. 2008. The antimicrobial efficacy of plant essential oil combinations and interactions with food ingredients. Int. J. Food Microbiol. 124:91-97. https://doi .org/10.1016/j.ijfoodmicro.2008.02.028.

Hassanien, M. F. R., S. A. Mahgoub, and K. M. El-Zahar. 2014. Soft cheese supplemented with black cumin oil: Impact on food borne pathogens and quality during storage. Saudi J. Biol. Sci. 21:280288. https://doi.org/10.1016/j.sjbs.2013.10.005.

Joana Gil-Chávez, G., J. A. Villa, J. Fernando Ayala-Zavala, J. Basilio Heredia, D. Sepulveda, E. M. Yahia, and G. A. González-Aguilar. 2013. Technologies for extraction and production of bioactive compounds to be used as nutraceuticals and food ingredients: An overview. Compr. Rev. Food Sci. Food Saf. 12:5-23. https://doi.org/10 .1111/1541-4337.12005.

Khorshidian, N., M. Yousefi, E. Khanniri, and A. M. Mortazavian. 2018. Potential application of essential oils as antimicrobial preservatives in cheese. Innov. Food Sci. Emerg. Technol. 45:62-72. https://doi.org/10.1016/j.ifset.2017.09.020.

Kong, E. F., J. K. Johnson, and M. A. Jabra-Rizk. 2016. Communityassociated methicillin-resistant Staphylococcus aureus: An enemy 
amidst us. PLoS Pathog. 12:e1005837. https://doi.org/10.1371/ journal.ppat.1005837.

de Lavor, É. M., A. E. B. P. Leal, A. W. C. Fernandes, F. P. R. A. Ribeiro, J. M. Barbosa, M. Gama e Silva, R. B. A. Teles, L. F. S. Oliveira, J. C. Silva, L. A. Rolim, I. R. A. de Menezes, and J. R. G. S. Almeida. 2018. Ethanolic extract of the aerial parts of Passiflora cincinnata Mast. (Passifloraceae) reduces nociceptive and inflammatory events in mice. Phytomedicine 47:58-68. https://doi .org/10.1016/j.phymed.2018.04.052.

Leal, A. E. B. P., A. P. de Oliveira, R. F. Santos, J. M. D. Soares, E. M. Lavor, M. C. Pontes, J. T. Lima, A. D. C. Santos, J. C. Tomaz, G. G. Oliveira, F. C. Neto, N. P. Lopes, L. A. Rolim, and J. R. G. S. Almeida. 2018. Determination of phenolic compounds, in vitro antioxidant activity and characterization of secondary metabolites in different parts of Passiflora cincinnata by HPLC-DAD-MS/MS analysis. Nat. Prod. Res. 2018. https://doi.org/10.1080/14786419 .2018 .1548445

Lima, M. C., M. C. C. Souza, I. F. Espeschit, P. A. C. C. Maciel, J. E. Sousa, G. F. Moraes, J. D. Ribeiro Filho, and M. A. S. Moreira. 2018. Mastitis in dairy goats from the state of Minas Gerais, Brazil: Profiles of farms, risk factors and characterization of bacteria. Pesqui. Vet. Bras. 38:1742-1751. https://doi.org/10.1590/1678 -5150-pvb-5698.

Maury, M. M., H. Bracq-Dieye, L. Huang, G. Vales, M. Lavina, P. Thouvenot, O. Disson, A. Leclercq, S. Brisse, and M. Lecuit. 2019. Hypervirulent Listeria monocytogenes clones adaption to mammalian gut accounts for their association with dairy products. Nat. Commun. 10:2488. https://doi.org/10.1038/s41467-019-10380-0.

Mohanta, Y. K., S. K. Panda, R. Jayabalan, N. Sharma, A. K. Bastia, and T. K. Mohanta. 2017. Antimicrobial, antioxidant and cytotoxic activity of silver nanoparticles synthesized by leaf extract of Erythrina suberosa (Roxb.). Front. Mol. Biosci. 4:14. https://doi .org/10.3389/fmolb.2017.00014.

Njongmeta, N. A., P. A. Hall, L. Ledenbach, and R. S. Flowers. 2005. 19. Acid-Producing Microorganisms. Pages 229-236 in Compendium of Methods for the Microbiological Examination of Foods. Y. Salfinger and M. L. Tortorello, ed. American Public Health Association, Washington, DC. 10.2105/MBEF.0222.024.

Oliveira, J. C., and C. Ruggiero. 2005. Espécies de maracujá com potencial agronômico. Pages 143-158 in Maracujá: Germoplasma e Melhoramento Genético. Vol. 1. F. G. Faleito, N. T. V. Junqueira, and M. F. Braga, ed. Embrapa Cerrados, Planaltina, Brazil.
Pereira, C. T. M., D. S. V. Oliveira, V. S. Veloso, S. S. P. Silva, L. S. Santos, A. F. L. Neto, F. A. Alcantara Oliveira, M. C. N. Melo, and M. J. Santos Soares. 2018. Microbiology quality, detection of enterotoxin genes and antimicrobial resistance of Staphylococcus aureus isolated from milk and Coalho cheese. Semin. Cienc. Agrar. 39:1957-1968. https://doi.org/10.5433/1679-0359 .2018v39n5p1957.

Rincón, A. A., V. Pino, M. R. Fresno, A. I. Jiménez-Abizanda, S. Álvarez, J. H. Ayala, and A. M. Afonso. 2017. Influence of vegetable coagulant and ripening time on the lipolytic and sensory profile of cheeses made with raw goat milk from Canary breeds. Food Sci. Technol. Int. 23:254-264. https://doi.org/10.1177/ 1082013216685202

Shan, B., Y.-Z. Cai, J. D. Brooks, and H. Corke. 2011. Potential application of spice and herb extracts as natural preservatives in cheese. J. Med. Food 14:284-290. https://doi.org/10.1089/jmf.2010.0009.

Siebra, A. L. A., L. R. Oliveira, A. O. B. P. B. Martins, D. C. Siebra, R. S. Albuquerque, I. C. S. Lemos, G. A. Delmondes, S. R. Tintino, F. G. Figueredo, J. G. M. da Costa, H. D. M. Coutinho, I. R. A. Menezes, C. F. B. Felipe, and M. R. Kerntopf. 2018. Potentiation of antibiotic activity by Passiflora cincinnata Mast. front of strains Staphylococcus aureus and Escherichia coli. Saudi J. Biol. Sci. 25:37-43. https://doi.org/10.1016/j.sjbs.2016.01.019.

Smith, T. C. 2015. Livestock-associated Staphylococcus aureus: The United States experience. PLoS Pathog. 11:e1004564. https://doi .org/10.1371/journal.ppat.1004564.

Tajkarimi, M. M., S. A. Ibrahim, and D. O. Cliver. 2010. Antimicrobial herb and spice compounds in food. Food Control 21:1199-1218. https://doi.org/10.1016/j.foodcont.2010.02.003.

Tayel, A. A., O. A. Abdel-Monem, S. H. Moussa, and A. I. Al-Turki. 2013. Plant extracts as antimicrobials: Prospects in food safety and health protection. Pages 311-326 in Plant Extracts: Role in Agriculture, Health Effects and Medical Applications. A. Giordano and A. Costs, ed. Nova Science Publishers Inc., Hauppauge, NY.

Tayel, A. A., H. Hussein, N. M. Sorour, and W. F. El-Tras. 2015. Foodborne pathogens prevention and sensory attributes enhancement in processed cheese via flavoring with plant extracts. J. Food Sci. 80:M2886-M2891. https://doi.org/10.1111/1750-3841.13138.

Vijayakumar, P. P., and P. M. Muriana. 2015. A microplate growth inhibition assay for screening bacteriocins against Listeria monocytogenes to differentiate their mode-of-action. Biomolecules 5:11781194. https://doi.org/10.3390/biom5021178. 